Sandra Leanne Bosacki*

ORCID: 0000-0001-9583-4582

St. Catherines, ON, Canada

Victoria Talwar**

ORCID: 0000-0001-9806-0279

Quebec, Canada
Valentina Sitnik***

ORCID: 0000-0001-7880-9895

St. Catherines, ON, Canada

Flavia Pissoto Moreira****

Maria Coccimiglio $* * * * *$

Shanel Quenneville******

St. Catherines, ON, Canada

\title{
Social Cognition, Self-Perceptions, and Social Withdrawal in Adolescents
}

\section{Poznanie społeczne, postrzeganie siebie i wycofanie się z życia społecznego u młodzieży}

Abstract: This study explored individual differences in emotion recognition within the context of social orientations and self-perceptions. One hundred and for-

* Prof. Sandra Bosacki, Department of Educational Studies, Brock University, email: sbosacki@brocku.ca.

** Prof. Victoria Talwar, Department of Educational and Counselling Psychology, McGill University, email: victoria.talwar@mcgill.ca.

*** Valentina Sitnik, Department of Educational Studies, Brock University, email: valentina.sitnik@brocku.ca.

**** Flavia Moreira Pissoto, Department of Educational Studies, Brock University, email: fla.pissoto@outlook.com.

***** Maria Coccimiglio, Department of Educational Studies, Brock University, email: maria.coccimiglio@brocku.ca.

****** Shanel Quenneville, Department of Educational Studies, Brock University, email: shanel.quenneville@brocku.ca. 
ty-four Canadian adolescents ( 88 girls, 11-14 years), with a mean age of 13.4 years completed emotion recognition, perceived self-competencies, social preferences (shyness, unsociability, and regulated withdrawal), and social (dis)satisfaction measures. The highest scores were related to epistemic or neutral emotions, followed by negative and finally positive emotions. Furthermore, there were relationships between high levels of emotion recognition (negative emotions) and low levels of physical and global self-worth. Positive correlations were found between high levels of shyness and the ability to recognise negative and epistemic emotions, and experience feelings of low self-worth, with girls scoring higher than boys in recognising positive emotions. Adolescents characterised by high shyness and high social satisfaction (i.e., conflicted shyness) scored the highest on emotion recognition and feelings of low self-worth. Implications for the refinement of theory and research on social withdrawal and social cognition are discussed.

Keywords: social withdrawal; social cognition; emotion recognition; self-perceptions; adolescence; loneliness.

Abstrakt: Niniejsze studium stanowi analizę różnic indywidualnych w rozpoznawaniu emocji, osadzoną w kontekście orientacji społecznych i postrzegania siebie. Stu czterdziestu czterech kanadyjskich nastolatków (88 dziewcząt, 11-14 lat) w wieku średnio 13,4 roku, pozyskało zdolność rozpoznawania emocji, postrzegania własnych kompetencji, preferencji społecznych (nieśmiałość, nietowarzyskość i regulowane wycofywanie się) oraz środków (dys)satysfakcji społecznej. Najwyższe wyniki dotyczyły emocji epistemicznych lub neutralnych, w dalszej kolejności - negatywnych i wreszcie pozytywnych. Ponadto istniał związek pomiędzy wysokim poziomem rozpoznawania emocji (negatywnych) a niskim poziomem poczucia własnej wartości, fizycznej i globalnej. Stwierdzono pozytywne korelacje między wysokim poziomem nieśmiałości a umiejętnością rozpoznawania negatywnych i epistemicznych emocji oraz doświadczeniem niskiej samooceny, przy czym dziewczęta uzyskiwały wyższe oceny w rozpoznawaniu pozytywnych emocji niż chłopcy. Młodzież charakteryzująca się istotną nieśmiałością i istotną satysfakcją społeczną (tj. nieśmiałością konfliktową) uzyskała najwyższe wyniki w zakresie rozpoznawania emocji i niskiej samooceny. W artykule omówiono implikacje dla udoskonalenia teorii i badań nad społecznym wycofaniem i społecznym poznaniem.

Słowa kluczowe: społeczne wycofanie; społeczne poznanie; rozpoznanie emocji; postrzeganie siebie; adolescencja; osamotnienie. 


\section{Introduction}

Recent research involving young adolescents demonstrated that motivations to either withdraw or approach others play a significant role in their social-cognitive development and well-being (Rubin et al., 2009). During the transition to secondary school, global research suggests that most young adolescents (approximately 11-13 years of age) experience challenges with their feelings of self-worth and identity, as well as their peer relations (Corsano et al., 2020; Eggum-Williams et al., 2019). For example, gender stereotypes within the high school environment can influence self-perception and peer relations (Maccoby, 1998; Walker, 2005). Such challenges may accentuate feelings of self-consciousness and feelings of low self-worth, especially for those adolescents who prefer to be alone (Corsano et al., 2020).

Despite the importance of studying the personal and social world of adolescents who self-select constructive solitude, or who tend to avoid or control their social experiences due to fear and anxiety (Ronchi et al., 2020), empirical support for the links between adolescents' preferences for social withdrawal and social-cognitive skills remains sparse, and the findings are inconsistent and variable (Bowker et al., 2016; Rubin \& Asendorpf, 1993; Rubin et al., 2009; Pequet \& Warnell, 2020; Wichmann et al., 2004). Studies show that throughout childhood and adolescence, mental state reasoning can be used as a social-cognitive mechanism for social orientations such as approaching or avoiding others (Thompson \& Thornton, 2014). For example, Nikolic et al. (2019) found that in school-aged children, high and low levels of mentalisation also referred to as Theory of Mind (ToM) or the ability to read mental states in others related to high levels of social anxiety, and were influenced by feelings of self-consciousness (Nikolic et al., 2019).

To further explore such links, the main purpose of this research was to explore individual differences and relations among social preferences, social cognition (particularly emotion recognition), and self-perceptions in adolescents. In particular, this study builds on developmental, constructivist theories of self-systems, social cognition, and social behaviour in that it explores how adolescents can use mental state reasoning as a possible mechanism for social preferences and self-evaluation (Kuhnert et al., 2017; Rose \& Rudolph, 2008; Vygotsky, 1978). This study also adds to past research that extends the unitary conception of social withdrawal (Eggum-Williams et al., 2019), and explores how adolescents' affective ToM skills, such as emotion recognition and their self-perceptions, may relate to preferences about sociability and 
solitude. Given that past research shows social withdrawal may be less tolerated and more of a risk for boys than for girls (Barry et al., 2015; Chen, 2019; Mewhort-Buist \& Nilsen, 2020), gender differences were also investigated.

\section{Social Withdrawal and Anxious Solitude}

Social withdrawal is a multidimensional process that includes one's preference for being alone, being removed and away from others, which may be motivated by a variety of reasons such as anxiety, negative emotions, and preference or affinity for spending time alone (Eggum-Williams et al., 2019; Maes et al., 2016). For example, unsociability is defined as a non-fearful preference for solitude, resulting from low social-approach and low social-avoidance motivations. That is, unsociable children may prefer spending time alone but are also socially adept at social interactions when invited or when they chose to engage with their peers (Chen, 2019).

Unsociability is distinguished from other motivations for social withdrawal such as shyness (i.e., high social-approach and high social-avoidance motivations) (Rubin et al., 2009; Eggum-Williams et al., 2019). Regulated withdrawal and avoidance represent the middle ground between shyness and unsociability (Bowker et al., 2019). Youth that exhibits regulated control lack strong approach motivations but at the same time have strong avoidance motivations. Such individuals regulate or manage their hesitant social contact with peers, seeking out opportunities for solitude with few signs of ambivalence or indecision (Coplan \& Armer, 2007; Nelson, 2013). The present study builds on these past findings and explores how shyness (preference for aloneness due to anxiety), unsociability (preference for aloneness due to an affinity for solitude), and regulated withdrawal (cautious and measured withdrawal from others) relate to emotion recognition and self-perceptions in adolescence.

\section{Theory of Mind and Self-Perceptions}

As part of the constellation or network of skills that make up social cognition, such as emotion recognition and perspective-taking (Wellman, 2014; 2020), the theory of mind is the understanding that people's observable actions are motivated by their mental states, including their intentions, emotions, beliefs, and desires (Doherty \& Perner, 2020). Subtle differences in 
using the theory of mind understandings, or 'the ability to read others' mind,' particularly the ability to identify emotions in others by viewing one's eyes has been found to help all ages of individuals (from a young child to adult) to make appropriate and accurate judgements about others' mental states (Viana et al., 2020). Such skill is associated with important social qualities and interactions with children and adolescents including peer coordination, cooperation, and empathy (Hughes, 2011). In the applied literature, poorer performance on theory of mind, particularly emotion recognition tasks, is associated with poorer interpersonal functioning and social competence challenges (Imuta et al., 2016; Ronchi et al., 2020).

The theory of mind plays an important role in interpersonal and intrapersonal functioning of adolescents, especially in the affective (how one feels about self and relations with others) and cognitive (self-evaluations) realm. The affective theory of mind which involves the ability to recognise or identify emotions in others (Wellman, 2020), develops in young children by the age of four and enables one to make sense of themselves and others in terms of thoughts and emotions (Wellman, 2020). This social skill becomes valuable to help adolescents carve out an identity for themselves (Białecka-Pikul et al., 2020), forming and maintaining peer relationships (Koerber \& Osterhaus, 2019). For example, some studies show adolescents who prefer solitude reported higher levels of perspective-taking, irony understanding, emotion recognition, and self-conscious emotions (Mewhort-Buist \& Nilson, 2020; Muris \& Broeren, 2009). In contrast, other studies indicate that adolescents who prefer solitude are more likely to have low levels of emotion recognition and self-worth (Ronchi et al., 2020; Colonnesi et al., 2017). Finally, some studies show no relationships between social preferences and ToM and self-perceptions (Colonnesi et al., 2017), or between ToM and social anxiety (Pequet \& Warnell, 2020). Accordingly, this study will address these gaps and contradictions in the literature on the affective theory of mind, social preferences, and self-perceptions in adolescents.

\section{Social Preferences, Self-Perceptions, and Social Cognition}

Mental state reasoning can also be used as a social-cognitive mechanism for social orientations in childhood and adolescence. According to past studies within a developmental, constructivist perspective (Bowker et al., 2019; Vygotsky, 1978), a developmental interplay takes place between children's motivations to either play alone or with others and their social-cognitive skills 
including emotion recognition and perspective-taking. For example, studies show links among social preferences for solitude and social play, the development of self-consciousness, and the onset of explicit ToM-related skills such as emotion recognition and perspective-taking start by the age of 4-5 years (Banerjee \& Yuill, 1999; Viana et al., 2020). Thus, the experience of shyness and unsociability continues to play a role in adolescents' self-consciousness and social development because it requires the ability to reflect on the self as seen by others, as well as be concerned about social evaluation (Pequet \& Warnell, 2020; Rubin \& Asendorf, 1993).

Similar to the first growth spurt of self-consciousness and social awareness (toddlerhood) (Dunn, 2005), the second wave of psychosocial growth in social and self-understanding and social relations occurs in early adolescence (Koch et al., 2020; Vanhalst et al., 2015). This second 'growth spurt' includes advanced mentalisation skills, such as emotion recognition and perspective-taking, crucial components of social cognition that enable individuals to discriminate effectively between social cues, interact with others, and constitute social groups (Doherty \& Perner, 2020). Such social skills are valuable in the process of social interactions and help youth to decide whether to avoid or approach others in social situations.

Adolescence also involves further development of epistemic emotions that relate to knowledge construction and reflection (Morton, 2010), as well as self-consciousness and achievement feelings, such as guilt, pride, and shame (Sette et al., 2020). Such complex emotions entail reflections and judgements of the self with perceived socially unaccepted behaviour and are especially relevant during the sensitive time of early adolescence when youth begin to self-reflect and self-evaluate (Denham, 1998; Maes et al., 2016).

\section{Role of Gender in Social Cognition and Social Preferences in Adolescence}

Given that gender is a social category that affects our social perceptions and actions (Heyder et al., 2020), gender-role stereotypes and expectations play an important role in early adolescence (Bowker et al., 2019). Research illustrates increased variability among girls' and boys' social skills and emotional experiences during secondary school (Hoffman et al., 2019). In particular, such gender differences become increasingly divergent in terms of adolescents' motivations to socially withdraw and the associated psychosocial factors such as perceived self-worth and social-cognitive skills. Further- 
more, it has been shown that during later childhood and adolescence, girls and boys may use their ToM skills differently in terms of their social skills and behaviour (Banerjee et al., 2006; Kuhnert et al., 2017). For example, past research shows compared to males, adolescent females with higher levels of social-cognitive abilities report more negative self-evaluations and social experiences (Hyde et al., 2008; Devine \& Hughes, 2013), higher levels of self-consciousness, especially regarding physical appearance (Bowker et al., 2019), and internalising challenges such as social anxiety and anxious solitude (Rudolph et al., 2020), depression, and self-harmful behaviours (Calandri et al., 2020; Hyde et al., 2008; Koch et al., 2020).

Studies on social withdrawal show that shy boys are at greater risk of socioemotional problems than shy girls (Coplan \& Armer, 2007; Ruble \& Martin, 1998), and run against gender-role stereotypical masculine or 'laddish' behaviours (assertiveness, initiative, etc.) (Heyder et al., 2020; Koch et al., 2020). Studies on social preferences (shyness, unsociability, regulated withdrawal) also show that due to societal expectations, shyness and unsociability may hold more negative psychological psychosocial implications for boys than for girls (Bowker et al., 2019; Rubin et al., 2002). That is, given societal stereotypic gender-role expectations, some adults may perceive shyness as a more stereotypic "feminine" trait, thus some adults may be more likely to accept and reward shyness in girls as compared to boys (Doey et al., 2014). In contrast, for boys, some adults may perceive shyness and unsociability as a negative personality characteristic, and shyness and unsociability may be more likely to be discouraged among boys as compared to girls (Coplan \& Weeks, 2010; Doey et al., 2014). Despite the claims that suggest adolescent girls possess a less coherent and positive self-theory than boys (Koch et al., 2020; Heyder et al., 2020; Maccoby, 1998), and studies that show girls use more frequent mental state talk than boys (Hughes \& Dunn, 1999; Pequet \& Warnell, 2020), differential gender links between social-cognitive skills and self-perceptions, especially in connection with social withdrawal during adolescence require further study. Thus, this study examines the complex web of correlates among preferences for social withdrawal, self-perceptions, and emotion recognition in adolescents.

\section{The Current Study}

To date, little research exists on social preferences and self-perceptions during the approach to adolescence, and how challenging peer experiences 
may influence psychosocial skills (Corsano et al., 2020; Wagner et al., 2020). For example, few studies explore why some youth decide to be alone, or avoid or withdraw from others, whereas some move towards others - and what motivates their social decisions? Thus, as past studies suggest, socially withdrawn youth may evidence a performance rather than a competence deficit (Bowker et al., 2019; Pequet \& Warnell, 2020; Wichmann et al., 2004). The present study builds on previous literature that shows socially withdrawn children may be more sensitive to others' mental states, communicative intentions, and judgements (Crozier, 1995; Poole et al., 2020), as well as being more likely to be more depressed, anxious and hold more negative self-perceptions than their more sociable age-mates (Cheek \& Melchoir, 1990; Rubin et al., 2002). With little research on social withdrawal and social cognition in adolescents (Page, 1990; Pequet \& Warnell, 2020), the present study aimed to provide insight into the two explanatory frameworks regarding whether or not a preference for solitude connects with either a deficit or a hypersensitivity in ToM skills (Nikolic et al., 2019).

This study also explored the role gender plays in the connections among emotion recognition skills and self-perceptions among shy, asocial, and regulated withdrawn adolescents, particularly investigating adolescents' responses (i.e., a general pattern of responses and gender-related differences) regarding 1) self-perceptions, 2) emotion recognition, and 3) social preferences. Based on past gender stereotype research in adolescence (Bowker et al., 2019; Saarni, 1999), gender-related differences in the findings were expected to reflect stereotypic gender-role expectations. That is, given that social reticence or passivity, emotion understanding and empathic concern are considered to be stereotypically feminine traits (Heyder et al., 2020; Maccoby, 1998; Rapee et al., 2011), girls were hypothesised to score higher on recognition of emotion in others and report more negative feelings directed towards the self.

\section{Method}

\section{Participants}

As part of a larger study of adolescents' social cognition and social behaviour within the school context, 144 adolescents $(88$ females, $M=13.4 \mathrm{yr}$, range $12.8 \mathrm{yr}$ to $13.6 \mathrm{yr}$ ) were recruited from eight schools within a mainly English-speaking, European-Canadian, middle socioeconomic status pop- 
ulation, in central-eastern Canada. This study focused on self-report measures only.

\section{Measures}

Perceptions of Self-Competencies Scale (PSCS; Harter, 1985). Drawing on past studies that assessed adolescents' self-knowledge (Koch et al., 2020), the present study used three subscales from Harter's (1985) perceived self-competencies scale, participants' self-views regarding moral behaviour or behavioural conduct, physical appearance, and an overall global sense of self or personal happiness (each subscale included six items). This measure is frequently used in social-cognitive research among youth (Corsano et al., 2020), with internal consistency reliabilities (Cronbach's alpha) for the three subscales ranging from .71 to .86 , with test-retest reliability ranges from .69 to .87 (Harter, 1985). For the present study, the internal reliability was as follows: perceived behavioural conduct (6 items, e.g., 'how well-behaved do you think you are,' Cronbach's alpha $=.81)$, physical appearance (6 items, e.g., 'how good-looking do you think you are,' Cronbach's alpha $=.79$ ), and global self-worth (6 items, e.g., 'how happy are you being who you are?' Cronbach's alpha $=.89$ ).

Reading the Mind in the Eye Test - Third Edition (RMET; Baron-Cohen et al., 2001). Participants completed this measure as a paper-and-pencil task in a group session which assessed participants' ability to recognise complex mental states. The measure involved 36 items with each item containing a photograph of expression with the eyes. Four descriptive words indicating different emotions were listed and the participant was required to choose the word that best described the expression. Each item had one correct answer and was scored as one point. Scores ranged from 0 to 36 with higher scores indicating a greater ability to read subtle emotions $(M=19.59, S D=4.718)$. Similar to Laghi et al. (2019), we also computed scores for distinguishing between positive ( 8 items), negative (12 items), and neutral (16) valence of emotions. The neutral emotions also reflective of epistemic emotions refer to emotions connected with the construction of knowledge and reflection, contemplation (Vogl et al., 2020). The validity of the RMET as a measure of advanced ToM skills (e.g. higher-order mental state reasoning, Koerber \& Osterhaus, 2019) is supported by studies that report significant correlations with conceptually similar measures such as the Faces subtest of the Cambridge Mindreading Face-Voice Battery for Children $(r=.35, p<.01$; 
Golan et al., 2015). Adequate internal consistency has been reported with young adolescents (Goldstein \& Winner, 2012) and good test-retest stability (inter-correlation $=.833$ ), was found with the Italian version of the RMET (Vellante et al., 2013).

Child Social Preference Scale (CSPS; Bayram Özdemir et al., 2015). Previous research indicates that the development and healthy functioning of adolescents is dependent upon social relationships (Bayram Özdemir et al., 2015). The CSPS is a 31 item self-report questionnaire which measured shyness, unsociability, and regulated withdrawal. The questions are divided into three subscales: shyness $=10$ items, unsociability $=7$ items, and regulated withdrawal $=14$ items. There is evidence for the construct validity of shyness and unsociability and the discriminant validity of unsociability. The construct reliability of the shyness subscale is $\alpha=0.875$, unsociability subscale is $\alpha=0.85$, and regulated control is $\alpha=0.85$.

Perceived loneliness and social dissatisfaction. To assess loneliness and social dissatisfaction at school (e.g., "It's easy for me to make new friends at school"), participants completed 16 items rated on a 3 -point scale $(0=$ no to $2=$ yes), and the measure was internally consistent (alpha $=.914)$. Adolescents' feelings of loneliness were assessed by the Loneliness and Social Dissatisfaction questionnaire (Asher et al., 1984) that contained 16 test items and 8 filler items. Participants responded to each item on a 5-point scale, indicating the degree to which each statement is a true description of themselves. Total scores thus ranged from 16 to 80, with higher scores indicating greater perceived feelings of loneliness and social dissatisfaction. This questionnaire, used in several studies with school-aged children, showed good internal consistency (Cronbach's $\alpha=.91$ ).

\section{Design and Procedure}

Upon receiving ethical clearance from university and school officials, this mixed-method study consisted of two stages. This study reports data from the first stage only which consisted of a group, in-class session where participants were group-administered tasks regarding self-perceptions. To ensure ethical guidelines were followed throughout, parental informed consent was obtained as well as verbal assent from the participants. Researchers administered the tasks to the participants within a quiet room within the school during school time and remained in the room as the participants completed the questionnaires to answer any potential questions from the participants. 


\section{Results}

To address the ongoing debate in the literature as to whether or not social withdrawal should be conceptualised as either a category to which one does or does not belong (Eggum-Williams et al., 2019) or as a dimension to which an individual varies on a continuum (Crozier, 1995), bivariate correlations were tested with shyness/social withdrawal and the main outcome variables with shyness as a continuous variable (not a dimension or categorical variable). Based on past studies (Coplan et al., 2019; Nelson, 2013; Poole et al., 2020), a person-centred analysis was conducted to explore if distinct groups based on social withdrawal subtypes and loneliness differed in their scores on the test variables.

\section{Descriptive Statistics}

Considering the sample sizes $(N>30)$, the violation of the normality assumption should not cause major problems (Pallant, 2007). However, the skewness statistics detected extreme values for the following variables: ToM1, CSPS's unsociability and regulated withdrawal subscales, Harter's global self-worth subscale (GSW), and loneliness and social dissatisfaction (LSD), according to the cut-off score of $3.29(50>300)(\mathrm{Kim}, 2013)$. Outliers were removed to handle the skewness. However, as no outliers were detected for GSW and unsociability, the subscales were log-transformed and non-parametric tests were conducted for not normal distributed scores to confirm results. Analyses were run with both the original data (with outliers removed) and with transformed variables, with all patterns of significance remaining the same. Thus, results are presented using analyses of the original data. Table 1 shows the descriptive statistics for the main test variables.

\section{Gender-related Differences in Emotion Recognition and Self-perceptions}

For the total sample, paired t-test results showed significant differences $(p=.000)$ among the RMET subscales with overall highest scores on neutral or epistemic emotions, followed by negative emotions, and finally positive emotions $[t=-12.68, \mathrm{p}=.018$, negative $>$ positive, followed by neutral $>$ 


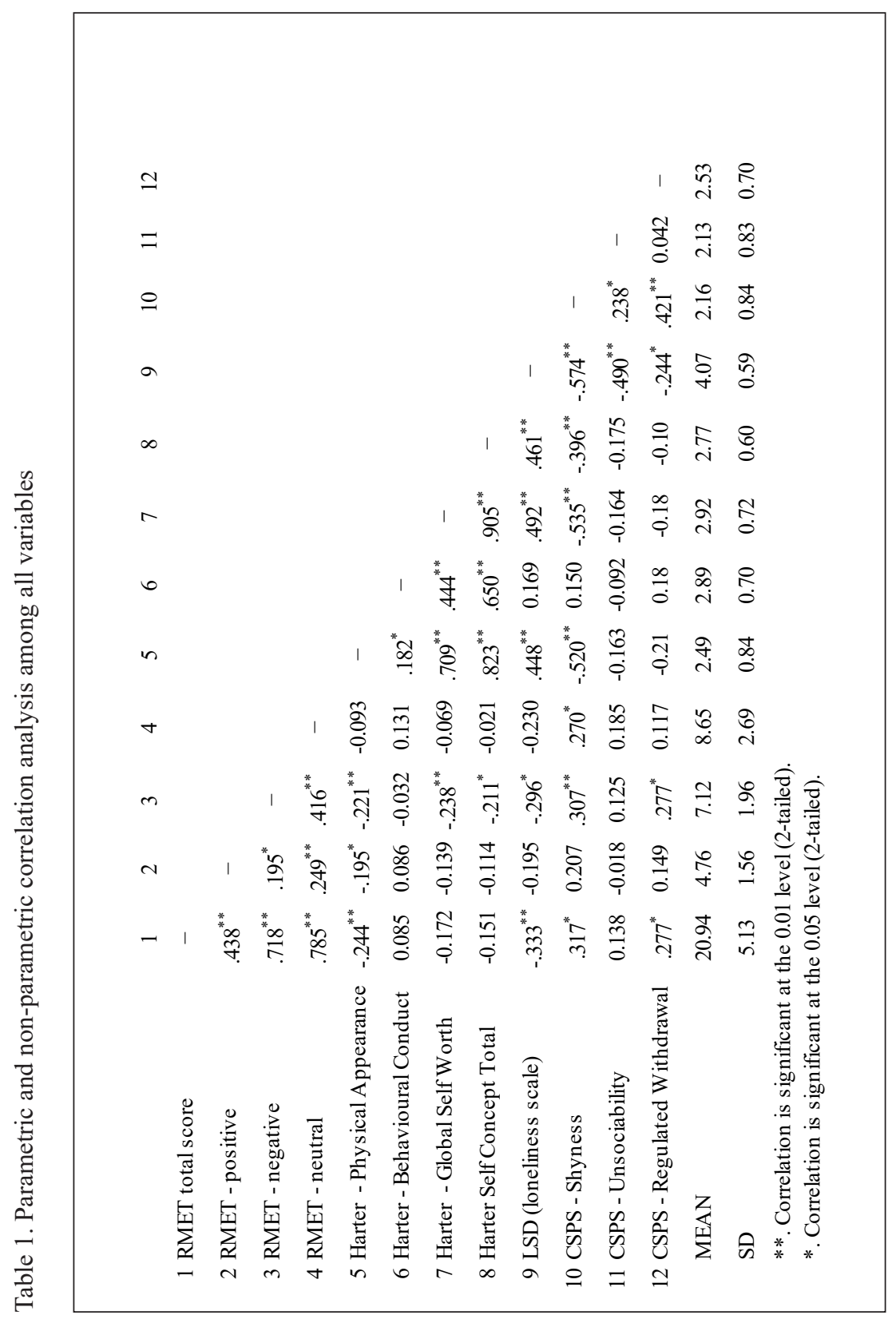


negative $(t=7.175)$ and finally positive $(T=-17.139$, neutral $>$ positive $)]$ (see Table 1).

To explore the research question of gender differences in the test variables, t-tests were conducted on all test variables with gender as the IV and DV was the main test variable. The main descriptive statistics and results of the t-tests for gender are presented in Table 1. Significant differences for gender were found for emotion recognition (RMET) total score, $t(127)=2.69$, $p=.01$, and in the positive emotion subscale, $t(143)=3.54, p<.01$, revealing that girls presented higher scores than boys in emotion recognition, especially recognising positive emotions. Girls also scored significantly higher than boys in perceived behavioural conduct $t(142)=2.23, p<.05$, whereas boys presented higher scores than girls in perceived physical appearance, $t(142)$ $=-2.44, p<.05$.

\section{Gender-Related Differences Across Social Preferences}

Table 1 shows gender differences among the main test variables assessed by t-tests. Examination of the means of the study variables revealed significant differences between girls and boys. The main results are summarised in the following section. There were no gender differences across the three social preferences (shyness, unsociability, regulated withdrawal), with girls scoring higher on the affective ToM (RMET), especially on the positive emotions (e.g., playful and friendly) compared to boys, whereas boys scored higher than girls on physical self-concept.

\section{Correlational Analysis}

Table 2 presents the bivariate Pearson intercorrelations for the main variables for the total sample $(N=141)$, showing a significant negative correlation between perceptions of global self-worth and affective ToM (negative emotions). That is, higher levels of the ability to recognise negative emotions (e.g., anger, distress) in others were linked to lower levels of global self-worth. Higher levels of the ability to recognise negative emotions also related to higher levels of preferred shyness and regulated withdrawal but not unsociability. Shyness was the only social preference scale that was positively associated with epistemic or neutral emotions, suggesting that youth who preferred social withdrawal due to fear or anxiety also scored higher 


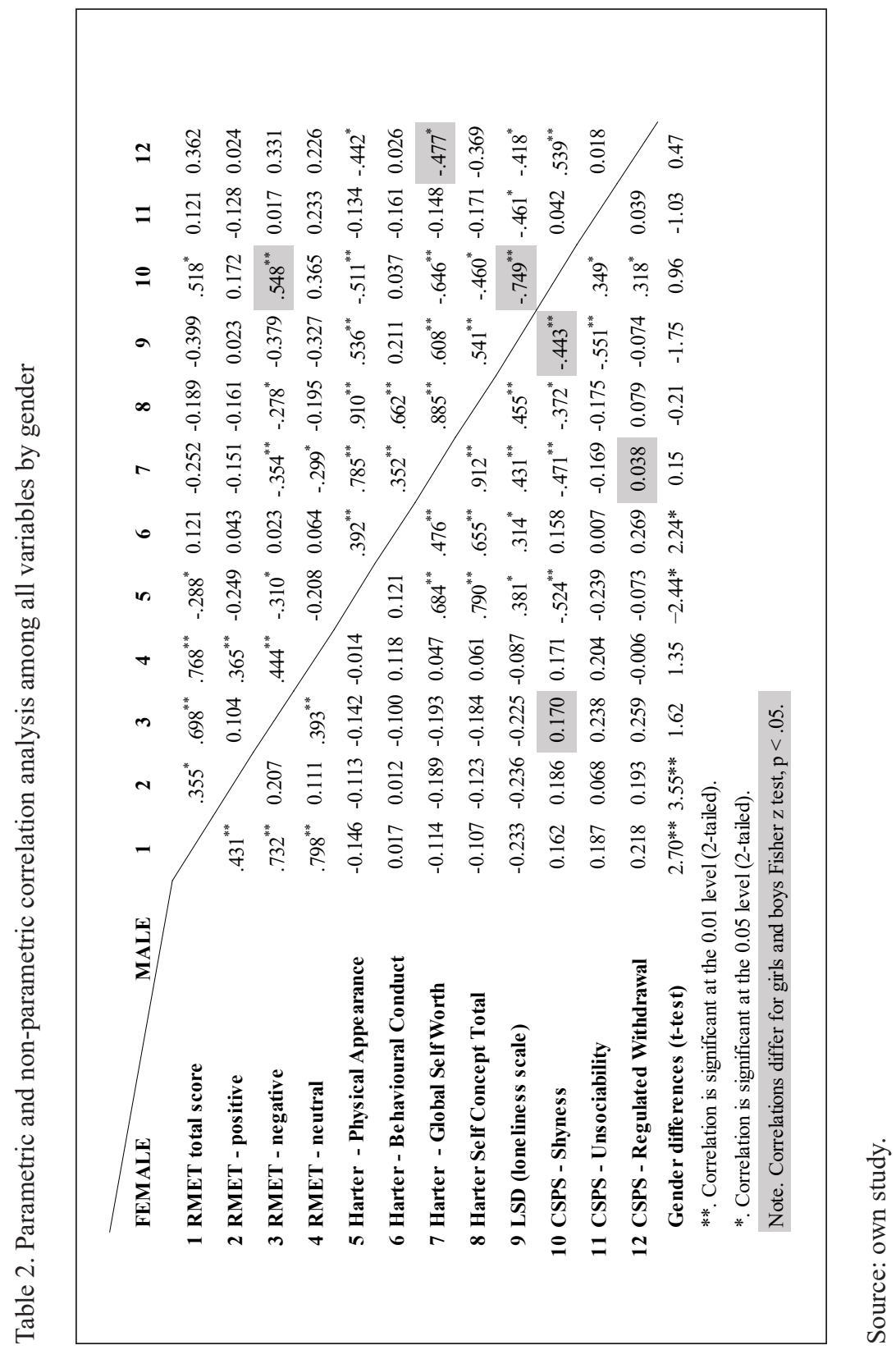


levels of recognising epistemic emotions that relate to knowledge, inquiry, and critical reflection (e.g., pensive and tentative) (Morton, 2010; Pekrun \& Stephens, 2012).

\section{Gender-related Correlational Differences}

Separate correlational analyses conducted on boys and girls (see Table 2) revealed a significant positive correlation between shyness and low global self-worth for both girls and boys. Among the boys only, significant positive associations were found between the preference for shyness and affective ToM (RMET total and negative emotions).

Z-tests were conducted to assess whether significant differences were present between the boys' and girls' correlations, showing significant gender differences in the magnitude of the correlations between regulated withdrawal subscale and perceptions of global self-worth $(z=-2.16, p=.03)$. Table 2 shows that boys who preferred high levels of regulated social withdrawal reported lower levels of overall global self-worth or were less likely to be happy being who they are. Alternatively, boys who preferred low levels of regulated social withdrawal (i.e., preferred more social interactions), reported higher levels of self-worth. No significant relations were found for girls.

Results from z-test also revealed significant gender differences between ToM and shyness correlations $(z=1.72, p=.04)$, with significant positive correlations found between ToM (RMET negative) and shyness in boys only, that is, only boys who were more likely to prefer social withdrawal due to fear and anxiety were also more likely to score high on affective ToM (RMET), especially negative emotions, or vice a versa - low ToM scores, low preference for shyness.

\section{Person-centred Approach - Social Withdrawal Subtypes}

Following the procedures of person-centred approaches used in past studies that show the utility of using a person-oriented approach to study social behaviour (Bergman \& Trost, 2006; Coplan et al., 2019; Maes et al., 2016; Nelson, 2013), we compared different types of withdrawn adolescents with their non-withdrawn counterparts in terms of indices of social cognition and self-perceptions. Extreme groups of socially withdrawn, unsocial, and 
regulated withdrawal adolescents were created based on scores of the social preferences scale.

Shy children $(n=7)$ had shyness scores in the top $25 \%$ and a preference for solitude or unsociability in the bottom $75 \%$. Unsociable children $(n=11)$ had a preference for solitude scores in the top $25 \%$ and preference for shyness and regulated control in the bottom $75 \%$. Regulated withdrawn children $(n=10)$ had a preference for regulated withdrawal scores in the top $25 \%$ and a preference for solitude and shyness scores in the bottom $75 \%$. Finally, non-withdrawn comparison adolescents had scores in shyness, unsociability and regulated withdrawal in the bottom $75 \%(n=29)$. Any participants who did not fit any of the above categories were not included in further analysis. Two sets of multivariate analysis of variance were conducted to assess differences in social preference groups for indices of ToM and self-perceptions. Chi-square analysis showed that the groups did not differ according to gender [Chi Square $(d f=3,1),=.233, p=.972]$.

The first MANOVA examined differences in self-reported competencies (physical, behavioural conduct, and global self-worth, as well as loneliness), showing a significant main effect of withdrawal group [Wilks' Lambda = $.516, \mathrm{~F}(3,1)=2.447, p=.003$, partial Eta squared $=.198]$. Subsequent tests of univariate effects indicated that shy adolescents scored the lowest on global self-worth, the comparison or non-withdrawn group scored the highest. For loneliness, the non-withdrawn group also scored the highest, with the unsocial group scoring the lowest.

The second MANOVA examined differences in self-reported cognitive and affective ToM (positive, negative, neutral emotions), showing a non-significant main effect of the withdrawal group [Wilks' Lambda $=\mathrm{F}(3,1)=.898$, $\mathrm{p}=.766$, partial Eta squared $=.957]$. Although non-significant, subsequent tests/posthoc analysis of univariate effects indicated that shy adolescents scored the highest on recognising emotions in others, and the regulated withdrawal group scored highest on understanding others' perspectives.

\section{Person-centred Analysis - Social Withdrawal and Social Satisfaction}

Given that the results showed shyness and loneliness were negatively correlated as continuous dimensions (e.g. high shyness levels related to low loneliness levels) similar to Poole et al. (2020), we furthered our person-centred approach to explore preferred social withdrawal and perceived loneliness or social (dis)satisfaction. Accordingly, four groups were created based 
on relative levels of shyness and loneliness or social dissatisfaction using a median split: sociable (low shy, low loneliness; $n=11$ ), introverted (low shyness, high loneliness; $n=21$; conflicted shy (high shy, low loneliness; $n=25$ ); avoidant (high shy; high loneliness $n=13$ ). Two sets of multivariate analysis of variance were conducted to assess differences in shyness and loneliness groups for indices of ToM and self-perceptions. Chi-square analysis showed that the groups did not differ according to gender [Chi Square $(d f=3,1),=.410, p=.522]$.

The first MANOVA examined differences in self-reported competencies (physical, behavioural conduct, and global self-worth), showing a significant main effect of shyness [Wilks' Lambda $=.251, \mathrm{~F}(3,1)=7.382, \mathrm{p}=.000$, partial Eta squared $=.100]$. Subsequent tests of univariate effects indicated that high shy and high lonely or avoidant adolescents significantly scored the lowest on physical appearance $\mathrm{F}(1,3)=7.556 . \mathrm{p}=.008$, partial Eta squared $=.025$; and the conflicted shy group scored the lowest on global self-worth $\mathrm{F}(1,3)=5.513 . \mathrm{p}=.022$, partial Eta squared $=.075$. Follow-up comparisons revealed that the conflicted shy group had a significantly lower score on global self-worth $(M=2.48, S E=.720,95 \%$ CI [21.48-27.32]) relative to the avoidant shy $(M=2.92, S E=.481,95 \%$ CI [14.35-24.15]), introverted $(M=3.32, S E=.55,95 \%$ CI [17.42-21.06] $)$, and sociable groups $(M=2.97$, $S E=.616,95 \%$ CI [18.69-23.04]).

The second MANOVA examined differences in affective ToM (positive, negative, neutral emotions), showing a significant main effect of shyness $[$ Wilks' Lambda $=F(3,1)=2.974, p=.019$, partial Eta squared $=.210$ ]. Subsequent tests of univariate effects indicated that shy and social adolescents (conflicted shy) scored significantly higher on emotion recognition (positive and negative emotions), $\mathrm{F}(1,3)=2.423, \mathrm{p}=.040$, partial Eta squared $=.199$. Follow-up comparisons revealed that the conflicted shy group scored significantly higher score emotion recognition $(M=24.364, S E=1.478,95 \%$ CI [21.48-27.32]) relative to the avoidant shy $(M=19.25, S E=2.45,95 \%$ CI [14.35-24.15]), introverted $(M=19.24, S E=.910,95 \%$ CI [17.42-21.06]), and sociable groups $(M=20.858, S E=1.096,95 \%$ CI [18.69-23.04]).

In agreement with Poole et al. (2020), we found that the high shy, low lonely group (high social satisfaction) or conflicted shy, scored highest on ToM but lowest on global self-worth. The MANOVAs were also calculated separately on split databases according to gender, revealing no significant differences, that is, the subgroup of conflicted shy adolescents reflected similar profiles irrespective of gender. 


\section{Discussion}

This study explored the individual differences and associations among adolescents' social preferences, emotion recognition skills, and self-perceptions, suggesting that motivations for being alone may differ according to one's gender, social-cognitive ability, and their self-perceptions. Positive relationships were found between social preferences for shyness and solitude and higher levels of emotion recognition, although high levels of shyness also related to lower levels of self-worth. Furthermore, gender differences were found in the relationships between social preferences, self-perceptions, and emotion recognition skills. Finally, the person-centred analysis showed that three distinct forms of social withdrawal (shyness, regulated withdrawal, and unsociable) based on different approach-avoidance motivations uniquely related to indices of social cognition and self-perceptions. Additional analysis showed that four distinct combinations of social withdrawal and sociability (introverted, avoidant, sociable, and conflicted shy) reflected different scores in social cognition and self-perceptions. Each of these main findings will be discussed in turn within the framework of past literature, followed by study limitations and implications for theory, research, and practice.

\section{Social Preferences, ToM and Self-perceptions}

The results showed that compared to unsocial and regulated control, shy children obtained high levels of emotion recognition and feelings of low self-worth and competence in one's physical appearance. Similar to Maes et al. (2016), we found that compared to the other sub-groups, conflicted shy adolescents appeared to be the most vulnerable or at-risk group (high shy, high social) given that they scored highest on emotion recognition and low self-worth. Also, compared to girls, boys who prefer regulated withdrawal reported lower levels of low self-worth and a more negative view of their physical appearance. Such results support past studies that show conflicted shy adolescent boys and adults are more susceptible to emotional challenges such as self-harm and addictions (Eggum-Williams et al., 2019; Page, 1990; Poole et al., 2020).

Gender-related differences found between emotion recognition and self-perceptions suggest that girls with high levels of emotion recognition were also more likely to prefer solitude, as well as report feelings of lower 
self-worth than boys. This result supports past studies that compared to boys, girls often report a higher frequency of negative self-perceptions (Meesters et al., 2017). Theory of mind in girls may help them read the mental states of others and to monitor the social actions of others (Qualter et al., 2013). Mental state reasoning may also enable youth to be anxious about social scenarios and how they may be perceived by their peers.

The present results also support the past research which suggests that compared to shy girls, shy boys may be the greatest at-risk for the development of socioemotional difficulties (Coplan \& Armer, 2007; Doey et al., 2014). Although we did not measure language ability in this study, the findings may have been influenced by language ability, as language skills may help to improve social facilitation for some shy boys (Coplan \& Armer, 2007). Future studies in adolescence need to explore the role of language and general cognitive ability in social cognition and preferences for solitude and sociability.

How do we explain the finding that only boys' (not girls) high levels of shyness related to higher levels of skill in reading negative emotions and feelings of low self-worth? This suggests that socially withdrawn boys compared to girls may be more adept at recognising others' negative facial emotions but similar to girls, higher levels of shyness related to lower levels of perceived physical appearance and reported lower levels of loneliness. Such findings support recent studies that show that socially vulnerable children (such as shy boys) who are repeatedly exposed to negative stereotyping are socially vulnerable and maybe hyper-vigilant in terms of recognising negative facial emotions in others (Chen et al., 2011). Thus, given the negative stereotypes of shyness in boys (Coplan et al., 2019; Mewhort-Buist \& Nilson, 2020), perhaps boys who are socially withdrawn are more vigilant at recognising other's emotions due to their hypervigilance.

In fact, for both boys and girls, higher levels of loneliness were related to lower levels of shyness (or vice versa), and a higher level of shyness related to lower levels of loneliness. As this finding reflects characteristics of conflicted shy youth (shy and sociable), similar to Poole et al. (2020), we speculate that for some adolescents, conflicted shyness may result from strong opponent processes to positive and negative emotions to real or imagined social situations, leading to conflicting social motivations. As past studies on conflicted shy youth suggest (Poole et al., 2020), such inner turmoil may have psychosocial implications for adolescents.

These findings highlight the need for longitudinal research on the psychosocial experiences of conflicted shy children and adolescents (Calandri et al., 2020). 


\section{Gender Differences in Social Preferences and Social Cognition}

From a developmental and contextual perspective, the present findings suggest that complex connections exist among perceived self-worth and emotion recognition skills may differ according to gender and social preferences, thereby supporting previous research that claims social interactions play significant roles in adolescents' social-cognitive and emotion understanding (Devine \& Hughes, 2013; Pequet \& Warnell, 2020). Overall, the results showed that compared to boys, girls were especially attuned to reading positive emotions in others, supporting the ambivalent sexism theory as well as benevolent attitudes towards women that suggest gender stereotypes emphasise patronising, paternalistic attitudes towards females (Glick \& Whitehead, 2010). Gender analyses also revealed that the relationships between ToM and perceived self-worth remained significant for girls' social preferences only, suggesting that the interconnections among social preferences, emotion recognition, and self-perceptions are more tightly woven in girls than for boys.

Thus, compared to boys and more social girls, emotion recognition may play a greater role in girls' preferences for social withdrawal and self-perceptions. The present study findings partially support research that suggests that dimensions of social withdrawal in boys might have perhaps not greater, but qualitatively different psychological costs compared to girls (Bowker et al., 2019). Perhaps in part due to cultural stigmas attached to stereotypic gender-role expectations and behaviour (Coplan \& Arbeau, 2008), the present findings suggest that there may also be some psychological costs for shy and unsociable girls, further adding to the growing body of contradictory evidence on gender differences in social preferences and social cognition adolescence.

The present findings also support the notion that advanced levels of mental state reasoning may carry intrapersonal and interpersonal costs as well as benefits (Devine \& Hughes, 2013; Nikolic et al., 2019; Sutton et al., 1999). For example, regarding interpersonal implications, adolescents with hypersensitivity to others' emotions and mental states may also use this ability to manipulate others in terms of taking advantage of collaborative tasks where they can socially loaf or avoid social responsibilities (Thompson \& Thornton, 2014; Wagner et al., 2020). The skill of reading others' emotions may enable some to emotionally harm others such as excluding one from a group by developing a friendship with someone else (Crick \& Nelson, 
2002; Sutton et al., 1999). As Dunn (2005) states, the ability to understand mental states in others does not predict one's social and moral actions.

Regarding intrapersonal consequences, mental state reasoning about others does not predict how to evaluate oneself in terms of competencies or feel about oneself in terms of kindness or coldness (Chaplin \& Norton, 2015). Indeed, conflicted shy youth who may be hypersensitive to other's mental states, may also experience feelings of insecurity and self-doubt about one's abilities and self-worth, which in turn may lead to self-destructive and harmful behaviours (Calandri et al., 2020; Hassan et al., 2020; Poole et al., 2020).

\section{Implications and Future Directions}

Our findings suggest that ToM ability may be of greater use in the creation of self-scripts or schemas for shy children, that is, in terms of emotional scripts and mental files theory (Doherty \& Perner, 2020), youth with high levels of emotion recognition and preference for solitude may be more likely to have a complicated mental file theory that provides multiple names for the same object (individuating label, conceptual and perceptual information). For instance, take the term 'friend', a shy teenager with high levels of emotion recognition skills may have more mental files with positive and negative characteristics (e.g., a friend is a kind person, a friend may try to sabotage my success, a friend may lie to me, etc.) compared to a person who has lower levels of emotion recognition (e.g., a friend is a kind person). As some studies suggest, some youth who prefer to withdraw from others due to a variety of reasons may be more sensitive to, thus skilled at reading the mental states of others (Pequet \& Warnell, 2020).

In addition, the mental file theory can also be combined with the opponent-process theory of emotion (OPT) that suggests affective states are modulated by opposing reactions (Poole et al., 2020). Thus, as our findings suggest, conflicted shyness may have resulted from strong opponent processes to both positive and negative emotions to real or anticipated social situations in some individuals, resulting in conflicting social motivations. Such an explanation would also help to make sense of the finding that youth who were conflicted shy (experienced high social satisfaction and high preference for social withdrawal) also scored the highest on affective ToM, especially the ability to read negative emotions in others.

Given that shyness is a social motivation to withdraw from others and biased in terms of threat and negative emotions, whereas sociability is a so- 
cial motivation to approach others and be biased towards positive emotions, conflicted shy individuals are related to higher hypervigilance to emotions, and heightened dual-activation of biological systems (Poole et al., 2020). Thus, future studies should continue to explore the complex dimensions of social withdrawal and interactions between sociability and preferences for solitude and how such preferences relate to emotion recognition and perspective-taking skills.

As conflicted and avoidant shyness are linked in the past to psychosocial maladjustment across development (Poole et al., 2020), educators need to be aware of the emotional and social needs of such students, especially during early adolescence when the peer group becomes increasingly important for one's developing identity and self-worth. Furthermore, socially avoidant and unsocial youth are sometimes missed by teachers in class due to their low and avoidant social profile (e.g. silent and out of sight, out of mind) (Coplan \& Arbeau, 2008; Eggum-Williams et al., 2019; Hassan et al., 2020).

Given the limitations of the present study (e.g., correlational design, lack of general language or cognitive measure, focus on the self-report, ethnically homogeneous sample), interpretations of the present findings should be made with caution. Furthermore, paper-and-pencil tasks and self-reports are unlikely to capture such a dynamic and complex process of the development of social cognition and social preferences and require more gender-specific measures (Nielson et al., 2019). Future studies could provide more explicit training for teachers and parents to model and incorporate compassionate and mindful talk into their conversations and private speech, and to look for behaviours that suggest anxious solitude in their students and children respectively. Overall, the present study suggests that mental state reasoning can be used as a social-cognitive mechanism for social orientations in adolescence, thus adds to the emerging literature on social cognition and social motivations within the secondary school context.

\section{References}

Asher, S. R., Hymel, S. \& Renshaw, P. D. (1984). Loneliness in children. Child Development, 1456-1464. doi:10.2307/1130015

Banerjee, R. \& Yuill, N. (1999). Children's understanding of self-presentational display rules: Associations with mental-state understanding. British Journal of Developmental Psychology, 17, 111-124. 
Banerjee, R., Rieffe, C., Meerum Terwogt, M., Gerlein, A. M. \& Voutsina, M. (2006). Popular and rejected children's reasoning regarding negative emotions in social situations: The role of gender. Social Development, 15, 418-433.

Baron-Cohen, S., Wheelwright, S., Hill, J., Raste, Y. \& Plumb, I. (2001). The "Reading the mind in the eyes" test revised version: A study with normal adults, and adults with Asperger syndrome or high functioning autism. Journal of Child Psychology and Psychiatry, 42, 241-251.

Barry, C. T., Loflin, D. C. \& Doucette, H. (2015). Adolescent self-compassion: Associations with narcissism, self-esteem, aggression, and internalizing symptoms in at-risk males. Journal of Personality and Individual Differences, 77, 118-123.

Bayram Özdemir, S., Cheah, C. \& Coplan, R. J. (2015). Conceptualization and assessment of multiple forms of social withdrawal in Turkey. Social Development, 24, 142-165. doi: 10.1111/sode.12088

Bergman, L. R. \& Trost, K. (2006). The person-oriented versus the variable-oriented approach: Are they complementary, opposites, or exploring different worlds? Merrill-Palmer Quarterly, 52, 601-632. http:// dx.doi.org/10.1353/mpq.2006. 0023

Białecka-Pikul, M., Szpak, M., Zubek, J., Bosacki, S. \& Kołodziejczyk, A. (2020). The psychological self and advanced theory of mind in adolescence. Self and identity, 19(1), 85-104. doi:10.1080/15298868.2018.1538900

Bowker, J. C., Ojo, A. A. \& Bowker, M. H. (2016). Brief report: Perceptions of social withdrawal during emerging adulthood in Lagos, Nigeria. Journal of Adolescence, 47, 1-4. https://doi.org/ 10.1016/j.adolescence.2015.11.006

Bowker, J., Ooi, L., Coplan, R. \& Etkin, R. (2019). When is it okay to be alone? Gender differences in normative beliefs about social withdrawal in emerging adulthood. Sex Roles, 82, 482-492.

Calandri, E., Graziano, F., Celino, E. \& Testa, C. (2020). Depressive symptoms and loneliness in early adolescence: The role of empathy and emotional self-efficacy. Journal of Early Adolescence, 1-25.

Chaplin, L. N. \& Norton, M. I. (2015). Why we think we can't dance: Theory of mind and children's desire to perform. Child Development, 86, 651-658.

Cheek, J. M. \& Melchior, L. A. (1990). Shyness, self-esteem, and self-consciousness. In H. Leitenberg (Ed.), Handbook of social and evaluation anxiety (pp. 47-82). New York, NY: Plenum Press. https://doi.org/10.1007/978-1-4899-2504-6_3

Chen, X. (2019). Culture and shyness in childhood and adolescence. New Ideas in Psychology, 53, 58-66. https://doi.org/10.1016/j.newideapsych.2018.04.007

Chen, X., Wang, L. \& Cao, R. (2011). Shyness-sensitivity and unsociability in rural Chinese children: Relations with social, school, and psychological adjustment. Child Development, 82, 1531-1543. 
Colonnesi, C., Nikolić, M., de Vente, W. \& Bögels, S. M. (2017). Social anxiety symptoms in young children: Investigating the interplay of theory of mind and expressions of shyness. Journal of Abnormal Child Psychology, 45(5), 997-1011. doi: 10.1007/s10802-016-02060

Coplan, R. J. \& Arbeau, K. A. (2008). The stresses of a "brave new world": Shyness and school adjustment in kindergarten. Journal of Research in Childhood Education, 22, 377-389.

Coplan, R. J. \& Armer, M. (2007). A "multitude" of solitude: A closer look at social withdrawal and nonsocial play in early childhood. Child Development Perspectives, 1, 26-32. https://doi.org/10.1111/ j.1750-8606.2007.00006.x

Coplan, R. J. \& Weeks, M. (2010). Unsociability in middle childhood: Conceptualization, assessment, and associations with socioemotional functioning. Merrill-Palmer Quarterly, (1982), 105-130. https://www.jstor.org/stabl e/23098037

Coplan, R. J., Ooi, L. L. \& Baldwin, D. (2019). Does it matter when we want to be alone? Exploring developmental timing effects in the implications of unsociability. New Ideas in Psychology, 53, 47-57. https://doi.org/10.1016/j.newideapsych.2018.01.001

Crick, N. \& Nelson, D. (2002). Relational and physical victimization within friendships: Nobody told me there'd be friends like these. Journal of Abnormal Child Psychology, 30, 599-607.

Crozier, R. (1995). Shyness and self-esteem in middle childhood. British Journal of Educational Psychology, 65, 85-89.

Denham, S. (1998). Emotional development in young children. New York: Guilford.

Devine, R. \& Hughes, C. (2013). Silent films and strange stories: Theory of mind, gender, and social experiences in middle childhood. Child Development, 84, 989-1003. https://doi.org/10.1111/cdev.12017

Doey, L., Coplan, R. J. \& Kingsbury, M. (2014). Bashful boys and coy girls: A review of gender differences in childhood shyness. Sex Roles, 70, 255-266. https:// doi.org/10.1007/s11199-013-0317-9

Doherty, M. \& Perner, J. (2020). Mental files: Developmental integration of dual naming and theory of mind. Developmental Review, 56, 100909. doi.org/10. 1016/j.dr.2020.100909

Dunn, J. (2005, June). Relationships and children's discovery of the mind. Paper presented at the annual meeting of the Jean Piaget Society, Vancouver, BC.

Corsano, P., Musetti, A. \& Favari, D. (2020). Self-concept, loneliness, and voluntary aloneness during late childhood. Current Psychology. https://doi.org/10.1007/ s12144-020-00675-7

Eggum-Williams, N., Danming, An., Zhang, L. \& Costa, M. (2019). Co-occurrence 
of cross-informant agreement on shyness, unsociability, and social avoidance during early adolescence. Social Development, 29, 73-88.

Glick, P. \& Whitehead, J. (2010). Hostility toward men and the perceived stability of male dominance. Social Psychology, 41(3), 177-185.

Goldstein, T. R. \& Winner, E. (2012). Enhancing empathy and theory of mind. Journal of Cognition and Development, 13, 19-37.

Golan, O., Sinai-Gavrilov, Y. \& Baron-Cohen, S. (2015). Cambridge Mindreading Face-Voice Battery for Children (CAM-C): Complex emotion recognition in children with and without autism spectrum conditions. Molecular Autism, 6(22), 1-9. doi: 10.1186/s13229-015-0018-z

Kim, H. (2013). Statistical notes for clinical researchers: Assessing normal distribution (2) using skewness and kurtosis. Restorative Dentistry \& Endodontics, 38, 52-54. doi:10.5395/rde.2013.38.1.52

Harter, S. (1985). Manual for the self-perception profile for children (SPPC). Denver, CO: University of Denver.

Hassan, R., Poole, K. \& Schmidt, L. (2020). Revisiting the double-edged sword of self-regulation: Linking shyness, attentional shifting, and social behaviour in preschoolers. Journal of Experimental Child Psychology, 196, 104842. https:// doi.org/10.1016/j.jecp.2020.104842 0022-0965

Heyder, A., van Hek, M. \& Van Houtte, M. (2020). When gender stereotypes get male adolescents into trouble: A longitudinal study on gender conformity pressure as a predictor of school misconduct. Sex Roles. doi: https://doi-org.proxy. library.brocku.ca/10.1007/s11199-020-01147-9

Hoffman, A. J., Dumas, F., Loose, F., Smeding, A., Kurtz-Costes, B. \& Régner, I. (2019). Development of gender typicality and felt pressure in European French and North African French adolescents. Child Development, 90, e306-e321. https://doi.org/10.1111/cdev. 12959

Hughes, C. (2011). Social understanding and social lives: From toddlerhood through to the transition to school. New York, NY: Psychology Press.

Hughes, C. \& Dunn, J. (1999). Theory of mind and emotion understanding: Longitudinal associations with a mental-state talk between young friends. Developmental Psychology, 34(5), 1026-1037. https://doi.org/10.1037/0012-1649. 34.5.1026

Hyde, J. S., Mezulis, A. H. \& Abramson, L. Y. (2008). The ABCs of depression: Integrating affective, biological, and cognitive models to explain the emergence of the gender difference in depression. Psychological Review, 115(2), 291.

Imuta, K., Henry, J. D., Slaughter, V., Selcuk, B. \& Ruffman, T. (2016). Theory of mind and prosocial behaviour in childhood: A meta-analytic review. Developmental Psychology, 52, 1192-1205. doi:10.1037/dev0000140 
Koch, M., Mendle, J. \& Beam, C. (2020). Psychological distress amid change: Role disruption during the adolescent transition. Journal of Abnormal Child Psychology. https://doi.org/10.1007/s10802-020-00667-y.

Koerber, S. \& Osterhaus, C. (2019). Some but not all aspects of the (advanced) theory of mind predict loneliness. British Journal of Developmental Psychology. doi:10.1111/bjdp. 1230

Kuhnert, R., Begeer, S., Fink, E. \& de Rosnay, M. (2017). Gender-differentiated effects of the theory of mind, emotion understanding, and social preference on prosocial behaviour development: A longitudinal study. Journal of Experimental Child Psychology, 154, 13-27. doi: 10.1016/j.jecp.2016.10.001.

Laghi, F., Cerutti, R., Terrinoni, A., Lonigro, A., Pongetti, A., Ferrara, M. \& Fantini, F. (2019). Evaluation of the "Reading the Mind in the Eyes Test" with non-suicidal self-injury (NSSI) adolescents: A pilot study. Current Psychology. https:// doi.org/10.1007/s12144-019-00505-5

Maccoby, E. (1998). The two sexes: Growing up apart, coming together. Cambridge, MA: Harvard University Press.

Maes, M., Vanhalst, J., Spithoven, A., Van den Noortgate, W. \& Goossens, L. (2016). Loneliness and attitudes toward aloneness in adolescence: A person-centred approach. Journal of Youth and Adolescence, 45, 547-567.

Meesters, C., Muris, P., Dibbets, P., Cima, M. \& Lemmens, L. (2017). On the link between perceived parental rearing behaviours and self-conscious emotions in adolescents. Journal of Child and Family Studies, 26, 1536-1535. doi: 10.1007/ s10826-017-0695-7

Mewhort-Buist, T. \& Nilsen, E. (2020). Shy children's understanding of irony: Better comprehension does not always mean better socioemotional functioning. Infant \& Child Development, e2131. https://doi.org/ 10.1002/icd.2131

Morton, A. (2010). Epistemic emotions. In P. Goldie (Ed.), The Oxford handbook of philosophy of emotion (pp. 385-399). New York, NY: Oxford University Press.

Muris, P. \& Broeren, S. (2009). Twenty-five years of research on childhood anxiety disorders: Publication trends between 1982 and 2006 and a selective review of the literature. Journal of Child and Family Studies, 18, 388-395. doi: 10.1007/ s10826-008-9242-x

Nelson, L. (2013). Going it alone: Comparing subtypes of withdrawal on indices of adjustment and maladjustment in emerging adulthood. Social Development, 22, 522-238. https://doi.org/10.1111/j.1467-9507.2012.00671.x

Nielson, M., Xiao, S. \& Padilla-Walker, L. (2019). Gender similarity in growth patterns of support toward friends during young adulthood. Social Development, 1-29. doi:10.1111/sode.12419 
Nikolic, M., van der Storm, L., Colonnesi, C., Brummelman, E., Kan, K. \& Bogels, S. (2019). Are socially anxious children poor or advanced mind readers? Child Development, 90, 1424-1441. doi: 10.1111/cdev.13248

Page, R. M. (1990). Shyness and sociability: A dangerous combination for illicit substance use in adolescent males? Adolescence, 25, 803-806.

Pallant, J. (2007). SPSS survival manual: A step by step guide to data analysis using SPSS for windows. New York, NY: McGraw Hill Open University Press.

Pekrun, R. \& Stephens, E. J. (2012). Academic emotions. In K. R. Harris, S. Graham, T. Urdan, S. Graham, J. M. Royer \& M. Zeidner (Eds.), APA educational psychology handbook: Vol. 2. Individual differences and cultural and contextual factors (pp. 3-31). Washington, DC: American Psychological Association. http://dx.doi.org/10.1037/13274-001

Pequet, A. \& Warnell, K. (2020). Thinking of you: Relations between mind-mindedness, theory of mind, and social anxiety in middle childhood and adulthood. Social Development. doi: 10.1111/SODE.12468

Poole, K., Khalesi, Z., Rutherford, M., Swain, A., Mullen, J., Hall, G. \& Schmidt, L. (2020). Personality and opponent processes: Shyness, sociability, and visual afterimages to emotion. Emotion, 20, 605-612. https://doi.org/10.1037/emo00 00574

Qualter, P., Rotenberg, K., Barrett, L., Henzi, P., Barlow, A., Stylianou, M. \& Harris, R. A. (2013). Investigating hypervigilance for the social threat of lonely children. Journal of Abnormal Child Psychology, 41, 325-338.

Rapee, R. M., Kim, J., Wang, J., Liu, X., Hofmann, S. G., Chen, J., ... Alden, L. E. (2011). Perceived impact of socially anxious behaviours on individuals' lives in Western and East Asian countries. Behaviour Therapy, 42, 485-492. https:// doi.org/10.1016/j.beth.2010.11.004

Ronchi, L., Banerjee, R. \& Lecce S. (2020). Theory of mind and peer relationships: The role of social anxiety. Social Development, 29, 478-493. https://doi.org/ 10.1111/sode. 12417

Rose, A. J. \& Rudolph, K. D. (2006). A review of sex differences in peer relationship processes: Potential trade-offs for the emotional and behavioural development of girls and boys. Psychological Bulletin, 132, 98-131.

Rubin, K. \& Asendorf, J. (1993). Social withdrawal, inhibition, and shyness in childhood: Conceptual and definitional issues. In K. Rubin \& J. Asendorf (Eds.), Social withdrawal, inhibition and shyness in childhood (pp. 3-17). Hillsdale, NJ: Lawrence Erlbaum.

Rubin, K., Burgess, K. \& Coplan, R. (2002). Social withdrawal and shyness. In P. Smith \& C. Hart (Eds.), Blackwell's handbook of childhood social development (pp. 329-352). London: Blackwell. 
Rubin, K. H., Coplan, R. J. \& Bowker, J. (2009). Social withdrawal in childhood. Annual Review of Psychology, 60, 141-171. doi: 10.1146/annurev.psych.60. 110707.163642 .

Ruble, D. \& Martin, C. (1998). Gender development. In N. Eisenberg (Ed.), Handbook of child psychology: Social, emotional and personality development (pp. 933-1016). New York: Wiley.

Rudolph, K., Monti, J., Flynn, M. \& Goodwin, G. (2020). Maladaptive consequences of emotional clarity deficits in early adolescence. Journal of Early Adolescence, 1-18. doi: 10.1177/0272431620912490

Saarni, C. (1999). The development of emotional competence. New York: Guilford.

Sette, S., Baldwin, D., Zava, F., Baumgartner, E. \& Coplan, R. (2020). Shame on me? Shyness, social experiences at preschool, and young children's self-conscious emotions. Early Childhood Research Quarterly, 47, 229-238. https:// doi.org/10.1016/j.ecresq.2018.12.012

Sutton J., Smith P. \& Swettenham J. (1999). Social cognition and bullying: Social inadequacy or skilled manipulation? British Journal of Developmental Psychology, 17, 435-450. https://doi.org/10.1348/026151099165384

Thompson, B. \& Thornton, B. (2014). Gender and theory of mind in preschoolers' group effort: Evidence for timing differences behind children's earliest social loafing. The Journal of Social Psychology, 154(6), 475-479. doi: 10.1080/00 224545.2014.933763

Vanhalst, J., Gibb, B. \& Prinstein, M. (2015). Lonely adolescents exhibit heightened sensitivity for facial cues of emotion. Cognition and Emotion, 31(2), 377-383. https://doi.org/10.1080/02699931.2015.1092420

Vellante, M., Baron-Cohen, S., Melis, M., Marrone, M., Petretto, D. R., Masala, C. \& Preti, A. (2013). The "Reading the mind in the eyes" test: Systematic review of psychometric properties and a validation study in Italy. Cognitive Neuropsychiatry, 18, 326-354.

Viana, K., Zambrana, I., Karevold, E. \& Pons, F. (2020). Emotions in motion: impact of emotion understanding on children's peer action coordination. Cognition and Emotion, 34(4), 831-838. Doi: 10.1080/02699931.2019.1669535

Vogl, E., Pekrun, R., Murayama, K. \& Loderer, K. (2020). Surprise-curious-confused: Epistemic emotions and knowledge exploration. Emotion, 20(4), 625-641. https://doi.org/10.1037/emo0000578.

Vygotsky, L. (1978). Mind in society: The development of higher psychological processes. Cambridge, MA: Harvard University Press (Original works published 1930, 1933, 1935).

Wagner, N. J., Bowker, J. \& Rubin, K. H. (2020). Associations between callous-unemotional traits and peer-rated social-behavioural outcomes in elementary 
and middle school. Journal of Abnormal Child Psychology, 48, 757-769. doi: 10.1007/s10802-020-00636-5

Walker, S. (2005). Gender differences in the relationship between young children's peer-related social competence and individual differences in theory of mind. Journal of Genetic Psychology, 166(3), 297-312. doi:10.3200/ GNTP.166.3. 297-312

Wellman, H. (2014). Making minds. How theory of mind develops. New York, NY: Oxford University Press.

Wellman, H. (2020). Reading minds: How childhood teaches us to understand people. New York: Oxford University Press.

Wichmann, C., Coplan, R. \& Daniels, T. (2004). The social cognition of socially withdrawn children. Social Development, 13, 377-329. 
